\title{
A Case Study on Rural E-commerce of selenium-rich Tea in Ziyang County
}

\author{
Junna Sun ${ }^{1,2 a}$, Hongzhen Lei ${ }^{3}$ \\ ${ }^{1}$ International Business Schoo, Shaanxi Normal University, Xi'an, China \\ ${ }^{2}$ Economics and Management School, Weinan Normal University, Weinan, China \\ ${ }^{3}$ International Business School, Shaanxi Normal University, Xi'an, 710119, China
}

\begin{abstract}
Ziyang County of Ankang city is one of the poor counties in Shaanxi Province. Due to the remote location and inconvenient transportation, it has not been able to remove the hat of the poor county. The birth of e-commerce has provided Ziyang County that can be have a concrete and feasible path of the development for poverty alleviation. On the one hand, e-commerce poverty alleviation has its unique significance and advantages. On the other hand, e-commerce development is limited by specific conditions and resources, so there are many difficulties in the development process. Taking the e-commerce development of selenium-rich tea in Ziyang County as an example, the problems encountered by e-commerce in the development of poor areas are hoped to find out in this paper, and then countermeasures are provided to solve the problems.
\end{abstract}

\section{Introduction}

\subsection{Background of the topic}

Since the reform and opening up 40 years ago, China's agriculture has entered a period of rapid development. In order to meet the developmental needs of modernization, it is necessary to coordinate the relationship between agriculture, rural areas and farmers [1]. Because it takes a good blacksmith to make good steel. The "rural revitalization strategy" proposed in the report of the 19th National Congress of the Communist Party of China means that China has changed its development thinking from "focusing on urban-rural coordination" to "activating rural potential". Rural areas are no longer simply seen as a weak link in social development, but as a starting point for social development. As a crucial year in the battle against the poverty, 2019 is the decisive threshold for achieving the first centenary goal. Since the pilot of e-commerce poverty alleviation in 2015, ecommerce poverty alleviation has made a series of achievements, so the power and contribution of ecommerce poverty alleviation cannot be ignored. For all this, there are still many problems in the development of e-commerce poverty alleviation in poor areas. Based on this, this paper takes the plight of Selenium-rich tea in Ziyang County out of the market as an example and tries to find a way to solve the common problems encountered in poor areas.

\subsection{Literature review}

The first person of putting forward the concept of electricity poverty alleviation is professor at the Chinese Academy of Social Sciences information research centre director Wang is defined as: electricity for poverty alleviation, poverty alleviation and development of ecommerce, is the age of the Internet today's mainstream ecommerce into the system of poverty alleviation and development work, ACTS on the recipients, innovative way of poverty alleviation and development, and the concept and practice to improve the performance of poverty alleviation and development[2]. The research on poverty alleviation by e-commerce is much earlier in foreign countries than in China. The first systematic research on poverty alleviation by e-commerce in China was conducted by Wang and Zhang on the poverty alleviation mode of e-commerce in Shaji Town, and the important significance and development ideas of ecommerce development in rural poverty alleviation and development were discussed [3]. By many scholars in recent years, the study of electricity poverty alleviation mechanism are more and more, almost every day study published about a similar problem, such as Lin in rural electricity function mechanism of poverty alleviation and the promotion mechanism research, poverty when it comes to electricity poverty alleviation of poverty in promoting mechanism and the relationship between the government, enterprises and individuals in poverty. And the rural industry development can be provided a development thinking [4]; $\mathrm{Li}$ and Yang in poverty alleviation and effectiveness of countermeasures and Suggestions to enhance rural electricity-based on Shaanxi, Ankang, Shangluo of Hanzhong city of three people think that in some poor areas development idea lag, the electricity business is mainly oriented by the government 
for poverty alleviation, which is associated with the market and product homogeneity serious, so that it causes that market competitiveness is not strong and so on. It accurate mentioned electricity encountered many problems for poverty alleviation [5]. In the investigation of the development mode of e-commerce in Huaiyuan County, Scholars such as Wang Ling and Ge emphasized that the current poverty alleviation of e-commerce in some poverty-stricken areas is still faced with the dilemma of poor logistics and transportation and the lack of ecommerce merchants [6].

The search, through previous scholars study the role of electricity, poverty alleviation, can be found on the way to help out of poverty through the electronic commerce research, which has made a more detailed classification. In this paper, the principle of the electric business mechanism for poverty alleviation, problems, countermeasures are wider, and thus the research of this paper is mainly concentrated $\mathrm{Yu}$ situation electricity poverty alleviation still with what problems and what new problem appeared again, list and put forward the corresponding countermeasure for guiding the poverty alleviation work.

\section{RESEARCH ON THE DEVELOPMENT STATUS OF RURAL E-COMMERCE INDUSTRY}

The saturation of the urban market will inevitably lead investors to look elsewhere, and there is no doubt that the countryside is becoming their new blue-water development. According to 43 times the China Internet network development state statistical report, as of December 2018, 829 million Internet users in China, the penetration rate of $59.6 \%$, of which rural scale of Internet users is 211 million, $26.3 \%$ of overall Internet users, in 2018, the Internet cover to further expand, "the last kilometre" poor area network infrastructure gradually get through, and "digital divide" to speed up the bridge, which laid a good foundation for electricity into the rural areas.

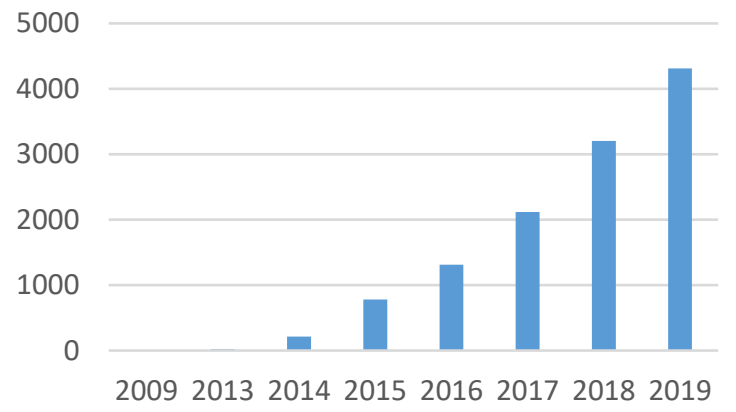

Fig1. The number of Taobao villages from 2009 to 2019

The blue Ocean dividend in rural areas has attracted the attention of well-known e-commerce companies in China. The research Report on China's Taobao Villages (2018) released by Ali research showed that in 2018, there were 3,202 Taobao villages and 363 Taobao towns across the country with 3,202 Taobao villages widely distributed in 24 provinces. On January 22, 2016, the Office of the State Council Leading Group for Poverty Alleviation and Development and Jingdong Group signed the "E- commerce Targeted Poverty Alleviation Strategic Cooperation Framework Agreement" in Beijing. By the second quarter of 2018, Jingdong e-commerce poverty alleviation covered 832 poverty-stricken counties and sold over 30 billion agricultural products. In 2018, "Suning Ecommerce Poverty Alleviation Training shop", a poverty alleviation model founded by Suning, has been established in 100 poverty-stricken counties with creating 3,500 jobs. Suning has helped entrepreneurs in more than 1,000 counties and towns to open more than 1,900 retail cloud stores through retail cloud. Suning is the first in the industry to set the 7th day of every month as "poverty alleviation Day". On the one hand, the poverty alleviation mode of many e-commerce enterprises has indeed promoted the prosperity and development of rural ecommerce and activated the vitality of rural areas. On the other hand, it has also won them the opportunity to occupy the rural market.

\section{PROBLEMS EXIST IN THE DEVELOPMENT OF RURAL E- COMMERCE INDUSTRY}

\subsection{The imperfect of rural logistics system}

To develop suppliers vigorously, logistics should be first. The improvement of the logistics is the most fundamental traffic flow. According to the relevant personnel investigation statistics, the pass rate of the asphalt in poor rural areas that is commonly known as the cement road is still far below the national standard and even their respective provinces. Except impassable roads, setting up the logistics system is one of the most important link in cold chain system. The cold chain system to establish the cost investment is very big and also become a big problem for the construction of electricity.

\subsection{Single financing channels}

That money is the foundation of all things, whether the talent or the basis of the related construction cannot leave the capital support. Due to the poor regions economic level is low, the relevant financial credit system is imperfect and even has not been established, so it is difficult to get financial institutions financing. Financing channel is single. It is unable to meet the demand of electricity development. As time goes by, it will affect the enthusiasm of electrical business professionals.

\subsection{The rare rural electric trader}

Rural population base is large. However, due to historical reasons, rural areas have low education level, and ecommerce professionals are even more difficult to find. Moreover, rural people with higher education often choose to live in big cities, and few of them go back to their hometown to find jobs or start businesses. Economic ability level is not enough to attract foreign talents. Therefore, the scarcity of professional talents is also an important factor hindering the sustainable development of 
rural e-commerce.

\subsection{The serious homogenization of products for sale}

In the later stage of poverty alleviation, e-commerce often finds the products that they sell are often the same or similar in the same region or adjacent different regions with the similarity of climatic conditions and geographical conditions. The homogenization of products is prone to cause vicious product competition, and the final loss is still the interests of the masses.

\section{THE BASIC SITUATION AND EXISTING PROBLEMS OF TEA PLANTATION IN ZIYANG COUNTY}

The conclusions drawn in this article are based on the common points of several examples. I have already elaborated on this point. In order to make these issues more three-dimensional, we will use the e-commerce road of selenium-rich tea in Ziyang County as follows Examples to explain these.

\subsection{Basic status quo of Tea farms in Ziyang County}

Ziyang is one of the poor counties in Shaanxi Province. It is located in the Qinba Mountains of China. Qinba Mountain area is a poor area in the south of Shaanxi province with an area of 2,204 square kilometres. The permanent population is about 2.8673 million. Ziyang County is mostly hilly. Most of the tea gardens are scattered, and farmers have the large input of care, low yield and low income. Moreover, the management, pruning and fertilization of tea saplings cost too much in farming time. However, the actual time of picking tea is only one month. Tea farmers' efforts far outweigh their harvest so that their enthusiasm is always low. Tea beverages in the market's pay attention to the first taste, and it followed by the appearance. Ziyang selenium-rich tea formerly rely on that the tea contains a lot of selenium element. It is one of the few methods in China that can produce rich in selenium tea party. So they hasn't been payed attention to tea appearance. Ziyang selenium-rich tea compared with the similar products on the market. The well-bred degree is not high, and it hasn't neat appearance. Due to the lack of the beauty of the famous tea (such as the west lake, "biluochun", dahongpao, pu'er tea) and its lack of market competitiveness, according to the survey on the market, most of ziyang tea is sold in the local, Ziyang seleniumrich tea stored in the provincial market is less. There is only one tea factory for export in the external market. Ziyang selenium-rich tea is almost invisible in some influential supermarkets.

\subsection{The problems in poverty alleviation of tea plantation e-commerce in Ziyang County}

\subsubsection{Single source of funds and sales channels}

Most tea farmers raise money by borrowing from relatives and friends to increase planting scale. Tea farmers are generally not familiar with the loan regulations of banks and credit cooperatives, and believe that the formal loan procedures and conditions as well as the requirements of formal financial institutions are harsh. Therefor it is not easy to obtain financial support. The farm tea of sales channels are also relatively simple. Tea farmers usually sell their tea to local tea factories, which then sell the finished leaves to local tea shops in Ziyang. These tea factories tend to be bought at relatively low prices. Because they sold at low prices. Most tea farmers cannot scale up or find other or better sales channels. As a result, many tea farmers are not willing to keep growing tea, but to find other ways to increase economic income and raise the level of income.

\subsubsection{The government's guidance is insufficient, and the local government has little training in e- commerce}

Tea farmers are lack of technical support. They need to seek for support from the local government or the relevant department of agriculture, which will be able to think of some ways to teach technology. The best treatment method is to be able to deal with some regular training classes with attentively guidance, or tea farmers hire some experts personally to the experimental base to guide farmers. However, according to most of the tea farmers, government rarely hold some related technical training or technical training tend to be some slick short words. There is not much practical effect. Tea farmers want to be coached on planting techniques and seek out more large tea buyers, which shows that tea farmers generally recognize the importance of planting techniques and want more distribution channels.

\subsubsection{Imperfect network construction and logistics distribution system}

At present, some villages and towns in Ziyang County still have low network coverage. Especially, the telecommunication and unicom network signals in rural areas are extremely unstable, and the high cost of accessing the Internet seriously hinders the enthusiasm of farmers' ecommerce businesses. Compared with cities, the infrastructure in rural areas is still very backward, which makes it difficult to meet the practical needs of ecommerce poverty alleviation. Although the countryside is the most close to the raw material, due to even get through from the village to the county, urban logistics cost is too high. So most of the major logistics of delivery site only extends to the township level, to the end of the village. A little way from the town is often ignored. This formation is the result of the seemingly from the county to the town of circulation unblocked. Since there is no connection, it is the most important raw material. Then the materials that they need to electricity can't come out from rural circulation, and also cannot let farmers profit from it. 
Therefore, getting through the last stage of logistics journey is of great significance to the cold chain logistics system of the whole county [7].

\subsubsection{Lack of poverty alleviation talents through e- commerce}

The development of rural electricity just began. Operating electric businessmen are more desire than ever before. Many people think they only can surf the Internet and build online store. This is a kind of electric business entrepreneurship. But it is a very biased opinion [8]. To shore up the electricity complete operation needs to multiple type. It needs to have more practical talents and Compound talents, which is not only to understand theory and technology, but also more to be good at marketing. While rural electricity required to master the basic knowledge of agriculture and to be able to use the different of farming will sell products in the countryside. Ziyang selenium-rich tea want to use e-commerce sales way. They need a lot of knowledge of theory, understand technology, and understand the tea science of electricity businessman just as support. However, the basic salary for the ecommerce person is not high due to the limited economic development. According to the electricity business areas in the electricity industry of Shaanxi province, all the staff average wages are generally lower due to the less attractive for pay conditions. It's very difficult for these electric businessmen to stay.

\section{COUNTMEASURES SHOULD BE TAKEN BASED ON THE DEVELOPMENT OF E-COMMERCE POVERTY ALLEVIATION MODEL OF ZIYANG SELENIUM-RICH TEA INDUSTRY}

\subsection{Improve rural network infrastructure construction and logistics distribution system}

To strengthen rural logistics infrastructure, the key is to solve the problem of "the first kilometre" and "the last kilometer". The government can improve the overall level of logistics infrastructure in Ziyang county by encouraging all walks of life to raise funds for charity, so as to attract other domestic logistics companies to participate in rural development and reduce farmers' logistics costs. Strengthening network infrastructure in rural areas is not only to achieve from the county to the town of complete coverage of network, but also to realize a complete coverage of from the town to the village of network. It is good for the rural logistics distribution sites and cold-chain system network track foundation, which improve the rural experience of online shopping, drive rural online shopping market, and promote the development of rural electricity.

\subsection{Integrate superior resources and improve industrial supporting facilities}

A solid industrial foundation is the prerequisite for the development and growth of e-commerce. E-commerce poverty alleviation is essentially an industrial poverty alleviation, and only by combining the two can it bring its economic and social benefits into full play [9]. In the past, Ziyang County rarely cooperated with merchants from the outside world. They usually cooperate to local production of local sales. Selenium-rich tea can be went to the country, and even the world market. The introduction of outside capital and reshaped the local resources are essential for a road. It will need to encourage farmers and merchants broaden horizons, actively cooperate with all kinds of market main body competition, and perfect in Ziyang tea picking, production, testing, sales in the integration of industry of form a complete set.

\subsection{Give play to the leading role of e-commerce talents and technology}

To improve population quality in poor areas of electricity is a necessary condition for poverty alleviation [10]. Through various channels to give full play to the existing electricity and mining businessman, it needs to develop targeted special preferential policies to attract those who have practical experience, to call on entrepreneurship to seek for college students to return home business for the rural poor areas of entrepreneurial talent to provide more policy support. So the entrepreneurial talent demonstration play a role of "leading" entrepreneurship. Third party e-commerce platforms (such as Taobao, Jingdong, Pindao, Suning) should be encouraged to combine with local e-commerce to sell local agricultural and side-line products on third party e-commerce platforms through local direct sales so as to guide more local farmers to set up shop on e-commerce platforms.

\subsection{Carry out all-round publicity and build famous brands}

The reputation of a product depends not only on the recognition of consumers, but also on the use of advertising to enhance its popularity, so as to open up the market. In the past, although Ziyang Selenium-rich tea has been promoted, it is difficult for consumers to distinguish the pros and cons of the products due to its self-labelling and various packaging products. To break this situation, they should support the leading enterprises as the leading role, which need to have the unified product packaging and after-sales service problems. The government should actively response and support. With led by the government, cable television and the government at the county site open selenium-rich tea column held in the school selenium-rich tea knowledge lecture and the tea production season rich selenium tea culture festival. It will strive to create strong atmosphere of the native district tea country and enlarge the influence of Ziyang selenium-rich tea.

\section{CONCLUSION}

E-commerce has injected new vitality into the cause of 
poverty alleviation, changed the flow of resources, technology and wealth from the social level, redistributed the profits of social development between urban and rural areas, and created conditions for the development of marginalized minority groups and those who have lost their labor force. With e-commerce as the carrier, the economic development of poor areas can be driven to form a circular poverty alleviation ecosystem and change the channels for poor groups to obtain resources and the opportunities to connect with the market. With the power of e-commerce, the poor areas can develop poverty alleviation industries, create employment and entrepreneurship opportunities, and increase people's income through multiple channels. Electrical business is a collection of social from all walks of life force for poverty alleviation precision of poverty alleviation. For example, Xi Jinping said: "we hold to mobilize the whole society to participate in, give full play to the advantages of the Chinese system, build the big government, society and market coordination to promote poverty alleviation pattern, and form a trans-regional, cross sector, across units and participation of the whole society in the plural social poverty alleviation system". It is to let the poor people really participate in them, break their previous dependence thought. Doing poverty alleviation is not equal to help the lazy. Helping the poor is not equal to help the stupid. It should fully mobilize the poor people to use e-commerce and participate in the e-commerce industry chain enthusiasm. Electricity can have a variety of patterns for poverty alleviation, which bring a lot of convenience for poverty alleviation work. The Ziyang selenium-rich tea industry is a small microcosm of China's poverty alleviation work for poverty alleviation. The effect would be increasingly protruding. Electric business platform for all participants can bring a sense of accomplishment and gain, thereby spurring a large number of poor body or social forces to participate in the industrial chain.

\section{Acknowledgment}

Rsearch project on major theoretical issues in Shaanxi social science field: Research on police mechanism of rural industry prosperity in Shaanxi province under the background of value chain recasting (2019Z057).

\section{References}

1. W. Ping. 40 Years of Reform and Opening up and The Economic Development of Agriculture, Rural areas and Farmers in China [J]. Taxation, 2018 (23) :237.

2. X. Wang. Four Questions on Poverty Alleviation through E-commerce [J]. Gansu Agriculture, 2015(13):18-20.

3. X.D. Wang, C.M. Zhang. New Ideas for Rural Poverty Reduction and Poverty Alleviation in the Internet Era-Enlightenment of "Sand Collection Mode" [J]. Informatization Construction, 2011(02):69.

4. G.Y. Lin. Research on the mechanism and Mechanism of Poverty Alleviation through Rural E- commerce [D]. Graduate University of Chinese Academy of Social Sciences, 2016.

5. C.X. Li, W.P. Yang. Countermeasures and Suggestions to Enhance the Effectiveness of Rural Ecommerce in Poverty Alleviation-Based on the investigation of Shangluo, Ankang and Hanzhong in Shaanxi Province [J]. Hubei Agricultural Science, 2018 (18):137-140.

6. L. Wang, H.X. Ge, Y.L. Nie, T.T. Yang, P. Yin. Investigation on the Development Mode of Ecommerce in Huaiyuan County [J]. Cooperative Economy and Technology, 2019(08):87-89.

7. J. Xia, S. Li, Q. Ye. Research on the strategy of "Big Data + Agricultural Product Logistics" in the Context of Great Poverty Alleviation [J]. Information Technology and Informatization, 2016(3):76-78.

8. D.F. Zhang, X.X. Yao. Research on E-commerce Poverty Alleviation through Targeted Poverty Alleviation [J]. Modern Management Science, 2018 (7):60-62.

9. H.F. Wang. Research on Main Problems and Countermeasures of Rural E-commerce poverty Alleviation [J]. Economic Review, 2018 (5):102-106.

10. L.S. Chen, C.H. Tan, J.J. Zhang. Case study of Ecommerce Poverty Alleviation Model and Its Replication Experience [J]. Economic Research Reference, 2018 (10): 10-14. 